\title{
Doing new materialisms: an interview with Maria Tamboukou
}

\author{
Maria Tamboukou \\ University of East London
}

\section{Beatriz Revelles Benavente \\ University of Granada}

\section{Received: 03/09/2019}

Accepted: 02/12/2019

DOI: https://doi.org/10.1344/jnmr.v1i1.30290

Including an interview as part of the issue responds to one specific question that has to do with the production of scientific knowledge. During the Training School (November 2017, Barcelona, Spain), the context in which this interview is framed, we highlighted the importance of creating inter-generational knowledges able to transverse across disciplines and the historicity of matter itself. We believed in the plurality of the voice as an intersection that allows de-centering the figure of the author as a hegemonic representation of scientific knowledge. This interview was performed in a very specific context and was opening the training school in order to find out how an onto-epistemological definition of new materialisms could affect a contemporary definition of feminist politics in order to elaborate a framework for non-hierarchical pedagogical practices. The interview that we are transcribing in this journal represents this specific moment between Beatriz Revelles-Benavente (co-editor and co-organizer of the Training School together with Ana M. González) and Maria Tamboukou, a recognized scholar on new materialist methodologies. The interview is divided into four thematic questions and we have reproduced the dialogue almost as it happened during the event: 


\section{New materialist methodologies}

Beatriz Revelles Benavente (BRB): I would like to start this training school by retrieving one specific definition of new materialisms from Nick Fox and Pam Alldred (2015, p.399), "New ¿or neo? Materialism [...] concerned fundamentally with the material workings of power, but focused firmly upon social production rather than social construction $[\ldots]$ how desires, feelings and meanings also contribute to social production." This implies conceptualizations of research and research inquiries as "assemblages", "processual", "affective", and many other qualifiers that situate the kind of research that is open up by this ethic-onto-epistemological umbrella that attempts to describe how matter comes to matter. This article reflects upon a processual methodology that embeds and embodies alternatives to realist or constructionist methods, the de-centralization of human agency, the conceptualization of research-assemblage and a moving towards an assessment of the micropolitics of the social. Taking into account that our speakers here are key figures in what seems to configure methodological strategies of new materialism. I would like them to explain to us how genealogies (van der Tuin, 2015) and narrative entanglements (Tamboukou, 2016; 2018) contribute to the reconfiguration of "material-discursive" practices of the world, on the one hand. And, on the other, taking into account that methodologies can be considered intra-actively working with ontologies and epistemologies in how practices matter, how these methodologies reconfigure a "new materialist" conceptualization on their own. That is to say, how can we practice methodologies engaging with the relation between acting and thinking (Tamboukou, 2016).

Maria Tamboukou (MT): In responding to this first question, I need to make an initial cartography of my theoretical and methodological approach to narratives.

1) Narrative research focuses on singularities, addressing the question of 'who one is'. At the heart of this proposition lies a philosophical tradition that focuses on difference rather than sameness and identity. In his major philosophical work, 'Difference and repetition' Deleuze (2004) has forcefully put forward the concept of pure difference, not different from, but different per se. I have expanded elsewhere 
on Deleuzian approaches to narratives (see Livholts and Tamboukou, 2015), but what I want to underline here, is the narrative interest on singularities, on the unique existent, the unrepeatable, who breaks away with the tyranny of representation and transferability, 'validity criteria' that have long been interrogated, particularly within the field of qualitative research in the human sciences. The narrative interest on the uniqueness of human beings is not however individualistic, an important point that brings me to my second proposition of the political matrix within which narrative research is deployed.

2) Narrative research is immanently situated within the political as conceptualized in Hannah Arendt's thought: I have used the Arendtian conceptualization of speech and action as the modes par excellence 'in which human beings appear to each other' (Arendt 1998, p.177), revealing as it were the uniqueness of the human condition. Indeed, action in the presence of others is a sine-qua-non condition for the emergence of the political subject. However, Arendt (1998) has pointed out that action is lost as the fleeting moment in the passage of time, if it is not transformed into a story. In thus following Foucault and Arendt, stories should not be conceived only as discursive effects but also as recorded processes wherein the self as the author/teller of his/her story transgresses power boundaries and limitations following 'lines of flight' in its constitution as a political subject. It is this very process of storied actions, revealing the 'birth' of the political subject that the political in narrative research is about. This political dimension should not therefore be conflated with 'the politics of emancipation' that narrative research has occasionally be hailed to: the researcher's emancipatory task of giving voice to the research participants, a trend and belief that has recently received quite important criticism. (See, Elliott, 2005)

3) Narrative research traces the constitution of 'the narratable self' (Cavarero 2000) This self is exposed from birth within the interactive scene of the world and through this constitutive exhibition, the self comes to desire the tale of his or her own life story to be told or written. The 'narratable self' is thus constituted within collectivities and out of culturally marked differences. But social milieus and collectivities are always in flux. The narratable self is therefore, discursive, provisional, inter-sectional, and 
unfixed. It is not a unitary core self, but rather a system of selves grappling with multilevelled differences and taking up subject positions, not in a permanent way, but rather temporarily, as points of departure for nomadic becomings.

4) Narrative research is a site of embodied knowledge: in Spinoza's monistic philosophy, mind and body are the same reality, though expressed in different ways. The body in its closed unity to the mind is therefore a site of auto/biographical knowledge because memory itself is embodied. In Cavarero's (2000) articulation of the narratable self, the auto/biographical exercise of memory is not about the self becoming 'intelligible'; it is rather about the experience that the self has of being narratable and therefore familiar. Each one of us knows that who we meet always has a unique story. And this is true even if we meet them for the first time without knowing their story at all. Moreover, we are all familiar with the narrative work of memory, which in a totally involuntary way, continues to tell us our own personal story (2000, p.33)

5) Narratives open up to the importance of the imaginary in what counts as research: Moira Gatens has underlined Spinoza's line of thought that without imagining that we can do something, we will actually never become able to do it (cited in James 2000, p.47). In this light, Genevieve Lloyd has further argued that Spinoza's philosophy has opened up possibilities for a reconceptualization of the imaginary and has discussed how Antonio Negri has read Spinoza's formulation of imagination as a path giving access to the realities of the social world: 'Imagination can play a constitutive role, rather than just a distorting one; in understanding its fictions, reason reflects on the real social world in all its confusion and contradictoriness' (Lloyd 1996, p.63).

6) Narrative research is closely interwoven with space /time deployments. In considering time and memory in narrative research, linear conceptualizations of time are abandoned: narrative research is not about linear temporalities; but rather about time contractions and rhizomatic formations, stories that contract the past that have made them what they are, starting from the middle, going back and forth, making connections with other stories of other times and other places. Narrative research raises questions about how the past is contracted in the telling of stories, what allows 
memory to have access to the pure past, how cultural memory works in the production and indeed narration of stories. These problematics around time and memory are further interrelated with question around spaces and places.

7) Narrative research is deployed in the whirl of the dance between power and desire: Desire in narrative is a theme much discussed and written about. As Teresa de Lauretis has put it: 'A story is always a question of desire' (2000, p.112). However, how desire is conceptualized and used is in itself an unresolved question analogous to that of the question of narrative and obviously psychoanalysis has been the field par excellence wherein questions of desire have been discussed and debated.

8) Stories however, are not just effects conditioned by relations of power, knowledge and desire. Stories do things: they produce realities. Narrative research is therefore about the constitutive power of stories in producing realities and indeed the subject. In my own research I have theorised women's narratives as technologies of the female self (Tamboukou, 2003). I have argued that women's narratives have operated as a critical technology of their self-formation, suggesting various and often contradictory political and ethical ways of 'becoming a subject'. However, narratives work with multifaceted power effects. As I have already argued narrative research informed by Foucauldian insights is concerned with the processes, procedures and apparatuses, whereby truth and knowledge are interrelated in the production of narratives and in their effects.

These eight propositions about narrative research are by no means exhaustive or final. I would rather suggest they be taken as research trails that can always be bent into different directions. They have been offered as tools in those strands of narrative research, exploring the multiple connections that difference in narratives can generate. Having recognized the fact that narrative research is a complicated field with multi-faceted levels of analysis, this does not mean that any route chosen within the narrative approach cannot be rigorous and systematic, creating of course its own norms, rules and taxonomies that work within particular contexts, what drawing on the work of feminist theorist Karen Barad (2007), I have called 'narrative phenomena' (Tamboukou 2014). What is at the heart of Barad's theorization is the recognition that 
entities can never be pre-defined, they always emerge through 'intra-actions' (Barad, 2007) within phenomena. Drawing on quantum physics, Barad has introduced the neologism of 'intra-actions' as a theoretical juxtaposition to the usual notion of interactions. In doing this she denotes a significant difference: while interactions occur between already established and separate entities, 'intra-actions' occur as relations between components. Entities-both human and non-human-actually emerge as an effect of these intra-actions, without having stable points or positions.

In this light the task of the narrative researcher is to map 'the narrative phenomena' she is working with and trace the emergence of entities, be they stories, themes, discourses, modes and of course narrative figures. In research, this question is explored on two interrelated planes: a) a theoretical plane wherein Foucauldian, Deleuzian and feminist lines of thought are making connections and b) a postnarratological plane where I chart how conventions of classical narratology are bent and how differentiations within various sub-genres of life writing, namely autobiographies, diaries and letters, emerge. What is central in this approach is the recognition and discussion of the fact that we are part of the storyworlds we seek to understand and therefore there can never be a clear-cut separation between 'the subject' and 'the object' of the research process.

Making connections between intra-actions in scientific experiments in the field of quantum physics and narrative research in the social sciences, what I want to argue here is that 'the researcher', 'the documents of life' and the 'research strategies of narrative analysis' cannot be taken as separate and pre-existing entities that interact in the final stage of the research process, the writing of an article or a monograph. The 'research findings' and consequently the published outputs rather emerge through the multifarious entanglements — both material and discursive-between 'the researcher', 'the research object' and 'the research context'. As a matter of fact, 'the narrative researcher', 'the documents of life' and 'the research context' are not predefined entities either: they are constituted through entangled intra-actions and their particular constitution can only hold within the conditions of the research process, the experiment or rather the 'narrative phenomenon' within which they emerge. Having 
mapped some of the complexities and intricacies of the field of narrative research, I can now retrace some of my research practices and methodological moves in the light of new materialism:

Being a Foucauldian from the very beginning I always start with a problem and throughout my work this problem has been understood as the emergence of female subjectivity within particular public milieus: education, art, work and in my very recent project in science and particularly mathematics (see Tamboukou 2003, 2010, 2015b, 2018) In this context I have always worked with narratives as traces of this emergence. And since you find such narratives in archives, I have also become very interested in what it is that we do when we work in archives. There are therefore two planes of entanglement that I am interested in while working with archives and narratives: a) entanglements of discourses and practices that have left their traces in narratives and b) entanglements of discourses and practices within the archive (see Tamboukou 2016)

In thus turning to the part of the question of what was reconfigured through this neomaterialist approach I will offer two examples from my work with 19th century French feminists (Tamboukou 2015b) that respond to the two levels of entanglements I have identified above:

Narratives and discourses have been central in writing a feminist genealogy of women working in the garment industry. What has also emerged as a catalytic event is the question of 'how matter matters' (Barad 2007) in the excavation of the conditions of possibility for the seamstress to emerge as a labour activist, a political subject, a writer of history and a creator of culture. While doing the literature review for this research, I was indeed quite struck to realize that women workers' role in the emergence of the autonomous feminist movement in Europe has been shadowed and marginalised in the history of feminism. More specifically, the fact that the founders of the first autonomous newspaper in Europe, 'La Femme Libre' were seamstresses, was just a footnote, a biographical detail that had not played any role in feminist historians' analyses, particularly in the way they have presented different trends and differences within this movement. To put it simply, my analysis took as its 
starting point the materiality of the seamstresses' work in understanding and ultimately reconfiguring the multiple becomings of feminist ideas in nineteenthcentury France and beyond.

Revisiting the archive of nineteenth-century feminism with a sensitivity to the materiality of its life documents has opened up different vistas of conceptualization and understanding. In the process of my research I have allowed myself to drift along the rhythms of the documents that I have been reading, analysing and writing about. Following Lefebvre's rhythmanalysis (2004), I have tried to listen to the rhythms of the documents I was reading, imagine the space/time continuum of their production, as well as the social and political conditions of their emergence. Locating for example the various addresses of the first feminist newspaper was in itself a concrete experience in the spatiality and materiality of the first feminist movement: it was from their homes that the seamstresses wrote and published, the same places where they would most probably work to make up for the meagre wages of their needlework. When an editor withdrew, the address would also change. From a neo-materialist perspective then, the geography of the newspaper revealed an intriguing history, or maybe the history of the journal can be starkly traced in its geography: its different addresses are thus the material traces of economic and social differences in the editorship, as well as in the theoretical and political orientation of the journal.

In finally responding the last part of the question about how we can enter into methodologies engaging with the relation between acting and thinking let me first summarise that in my approach the archive is taken a) as a living organism, and thus as a process in becoming but $b$ ) it is also theorised in the light of the philosophies of 'the event'-that is my argument is that the archive is 'an event', an eruption that marks discontinuities and ruptures in our habitual modes of understanding and knowing.

What I have therefore suggested is that the materiality, temporality and sociality of the archive is crucial for the entire research process and that as researchers we should not separate the physical, social and intellectual dimensions of the archival research we carry out. 


\section{Causality in new materialist methodologies}

BRB: At the beginning of the two-thousands, feminist contemporary theory (in Grosz, 2004) already warned feminism to move beyond static results because they were already part of the past. Some voices of new materialist research claim the necessity to move away from linear causalitations in research. For example, the work of Iris van der Tuin (2015) specifies two imbricated movements in order to produce knowledge. On the one hand, she encourages to think through quantum leaps that enable a reiteration of past, present and future in order to avoid claxifying feminist genealogies. On the other hand, she interpellates the unknown since since "what happens next is unknown, because every end result is always already a new point of origin." (van der Tuin, 2014, p.231) In your work, you explain knowledge as "emerg[ing] through new begnnings and unexpected connections in the web of contingent relations that constitute reality." (Tamboukou, 2015a, no page)

Nevertheless, without the predictability that certain areas of social research provide to social problems, certain approaches remain vague or obscure since static results are not possible for this kind of approach. How would you explain this conceptualization of causality for interdisciplinary contexts? What would be the empirical application of this nonlinear causality? And how does this affect to individual/and/or agential capacities? Your work is predicated on affirmation, on the power of the conjunction "and", in order to configure a theorization of new materialism. How can we configure this "and" (instead of a linear result) as the catalyst for political transformations in society? Could we say that this is potentially the openness of a radical future and the territorialisation of the social in New Materialism?

MT: What I think is at the heart of understanding the debates and problematics around causality is the important notion of 'the event'. Early on in my work I was very much interested in what Foucault had configured as 'eventalization' (1986) in a genealogical understanding of history. Put it simply I got interested in the question of 
how we deal with unexpected eruptions, counter discourses and revolutionary events in the order of discourse, the status quo of social realities and ultimately the flow of history.

We are continuously confronted with such events, take the Parisian May events in 1968, or more recently the Arab spring events and in my recent research, the emergence of the first autonomous feminist movement in France. These were all 'untimely' events to put it in Grosz's words (2004) and their linear causalities were constructed a posteriori in the historiographical operation or in sociological and cultural analyses of their geographies and times. To put it bluntly, it is always easy to look back at an event and discern and map linear causalities. In my work I have instead raised the question of how sociologists can study temporal and singular events in a continuous process of being modified, influenced by Whitehead's understanding of reality as process (1985). As Steven Shaviro (2012, p.17) has succinctly put it, for Whitehead 'the world is made of events, and nothing but events: happenings rather than things, verbs rather than nouns, processes rather than substances'. And here is the leap to quantum physics which has revolutionized our understanding of the deep structure of reality. Material objects have dissolved into wave functions that lack well-defined properties, interact non-locally, and collapse into particles in non-deterministic ways that are inseparable from the subjects who measure them. Barad's (2007) work has of course been influential here particularly in showing how quantum processes are not only relevant for the most microscopic level of reality; but also for explaining consciousness, and by extension, human social life.

Drawing on Whitehead I have actually problematized and questioned the notion of serendipity, arguing instead that it is our entanglement in and emergence from the world in the midst of entangled causalities and events that makes serendipity as a recurrent theme in how we frame for example our findings and understandings in the archive (see Tamboukou 2016). So to go back to your question about 'the relevance' of non-linear causalities within particular social and political contexts, I suggest that instead of linear causalities, we should be interested in 'causal efficacy', a notion in 
Whitehead's process philosophy which according to Michael Halewood 'points to the manner in which our material being and our beliefs and actions are always located within a realm of efficacy, of a passing-on of date, of reasons, of motions, of feelings'. (2013, p.54-55) This is not to say that any of these are strictly caused by that which precedes them, ie linear causality, but it does point to the absurdity of denying cause altogether or locate it as a natural or human phenomenon easy to discern and identify.

I believe it important to start accounting for contingencies and becomings: how to unsettle linear analyses about 'social facts and social orders', which have been the traditional objects of sociology, but also how to include in the analysis possibilities that have not been actualised but can be considered within a plane of radical futurity. Here I have followed Deleuze and Guattari's suggestion (REF) that societies should not be defined by their order, but by what escapes their order; in this line of thought, as researchers we should become more sensitive to the untimely, the inventive possibilities of life and its power to open up the future to the unpredictable, the unforeseen, a world yet to come. That is why I would rather follow Shaviro's (ix) pithy observation that Whitehead's understanding of reality as process moves the analytical interest from the philosophical question of 'why is there something rather than nothing' to the more sociologically driven one of 'how is it that there is always something new?'.

\section{The object of feminism: $w(0) m(a) n$ ?}

BRB: Now it is time to turn to the much of the contemporary debate of feminism, that is the concept of woman. From queer theories and other non-anthropocentric theories the concept of woman seems to be in dispute, as much as it was the concept of gender at the beginning of the two-thousands. Nevertheless, it is important that from a feminist angle we are able to discuss and reflect upon how do we envision the object of feminist theory, the (im)possibility of defining such a concept. Using a new materialist framework, or rather in your own words, what is the configuration of "woman" or "female" or a "feminine identity/subjectivity" through a new materialist 
sense? Does it make any sense to maintain categories such as woman or women or feminine or gender for a feminist conceptualization of politics? If not, how do we build a feminist politics of new materialism?

MT: This is a fair question that is always being posed when we enter new materialism territories and debates and of course there have been various and contradictory responses to this question, which I believe could be answered from two entry planes of thought that are the onto-epistemological plane and the ethico-political frame:

1. The onto-epistemological plane that links with the first question in this dialogue:

Gender relations, femininities, masculinities, gender-based violence and so on and so forth belong to what Whitehead (1985, p.129) has configured as 'the stubborn fact' of the past. Whitehead's philosophy configures reality on both a microscopic and a macroscopic level and highlights the fact that process should be understood as both flux and permanence. On the one hand, there is the problem of following the process wherein each individual unity of experience is realized. On the other hand, there is a recognition of some actual world out there, already constituted, 'the stubborn fact which at once limits and provides' according to Whitehead (ibid.); that is, the reality of matter that stays on while passing through flows and transformations. In this light, 'the stubborn fact', which belongs to the past, inheres in the flowing present wherein actualities are being constituted. This coexistence of permanence and flux creates conditions of possibility for the future, which is anchored in the present but has not been actualized yet. Attentiveness to 'the stubborn fact' is the weak link of all modern philosophies, Whitehead has remarked. (ibid.) 'Philosophers have worried themselves about remote consequences, and the inductive formulations of science. They should confine attention to the rush of immediate transition', to the fact that 'we finish a sentence because we have begun it, we are governed by stubborn fact'. (ibid.)

Put it simply, there is a world out there solidified and crystallized with phenomena and problems that we need to address, simply because we have no choice. New materialist approaches are actually enhancing our understanding of the complexities of 'the stubborn fact of the past' (Whitehead 1985, p.129). 
2. The ethico-political plane of response:

As an archive of knowledge, feminist theories have actually been pivotal in such understandings and analyses. Kathy Ferguson (2017) has recently argued that despite its many differences, feminist theories are not only about women, but about the world: reliably suspicious of dualistic thinking, generally oriented toward fluid processes of emergence rather than static entities in one-way relationships, and committed to being a political as well as an intellectual enterprise. We have already discussed how neo-materialist approaches are at the heart of these areas. What is important to remember here is that new materialism is a toolbox of approaches to the problems of our actuality, not its solution.

In light of the above, when we talk about 'women' or 'men', female and/or feminine identities, subjectivities or even stances and subject positions we refer to this 'stubborn stuff of the past that has already been solidified as women's historicity, oppressive gender relations and intersectional power regimes that we cannot disregard in the name of the slow, on-going flows and changes. This acknowledgement of the 'stubborn fact of the past' however, does not throw us back to essentialism. It just makes us aware of the fact that apart from their historicity in the philosophy of process, 'women' and 'men' as embodied and intersectional entities create ethico-political platforms and situated positions for changing gender relations and the subject, amongst other critical areas of challenging the status quo of this world.

\section{Towards a feminist scientific canon}

BRB: To conclude with this set of questions, and in order to provide a framework that transverses different angles important for feminism and for pedagogies in general, I would like to turn now to the problem of the scientific canon. This was already voiced by Donna Haraway (1988) under the primacy of vision. What gets to be transmitted pedagogically and historically, how do we construct knowledge upon certain powerful regimes and not others, how do we know what we know without falling into God 
Tricks (ibid). Taking into account that new materialism is an emerging framework that aims at explaining reality through processes and not static results, how do we envision our contemporary archive. What do you think is it the relation of contemporary theories of new materialism with, for instance, Hemmings' (2011) politics of citation? Do you think that there is a trend to homogenize the knowledge of new materialism under the names of few contemporary and non-contemporary philosophers? Do you consider that the diversity present in disciplines, approach to politics, and feminist traditions is widely represented for a lack of a better word?

MT: First of all I think that Clare Hemming's politics of citation (2011) is a very useful angle to look at how the archive of feminist theory is being constituted as we speak. However, Hemming's approach creates its own system of classifications and taxonomies and this inevitably includes some lines of analysis and excludes others, since there is simply no system of ordering that does not work through continuous openings and closings, inclusions and exclusions. My question therefore is not about whether exclusion is at work, but rather who or what gets excluded and with what effects.

Since archives of knowledge, feminist theories and new materialist approaches included, are always constituted through inclusions and exclusions, all we can do is to keep adding 'and, and, and,' instead of trying to add and frame the field, whatever the scheme we use. For example, I have found Hemming's (2011) tripartite schema of 'progress', 'loss' and 'returns' very restrictive: not only does it include, as much as it excludes, it also 'forces' citations and works within its categories. What we have tried to do within the network is to create some tools that could challenge hierarchies of knowledge [and citations]. Instead of creating a glossary for example, we have created an 'almanac' of notions, instead of creating a bibliography, we have instead opted for an autobibliography. The idea of the 'almanac' offers a more playful image of how archives of knowledge are crafted and recrafted. (see http://www.newmaterialism.eu/almanac) The notion of autobibliography shows how we create bibliographies through our own experiences of reading and learning, that is from specific and situated positions (see http://newmaterialism.eu/auto- 
bibliography). I am not saying that this will solve the problem, but at least in can be a playful engagement with the archive.

Having situated my position vis-à-vis Hemming's and indeed any politics of citation, I do think there is a problem with putting everything under the umbrella of new materialism. We are more or less in agreement by now that we cannot take 'new materialism' in the singular, so the epistemological move towards creating a plane of consistency in grappling with the incoherence of knowledge within new materialisms and beyond is I think an important contribution. Some of the conceptual novelties that emerge from making cartographies within this new materialism plane include amongst others:

a. the Spinozist material turn towards affect-laden subjectivities and epistemologies (see Lloyd 1996);

b. an intensification of theorizing the concept of nature and challenging the fallacy of bifurcation led by Isabelle Stenger's insights of Whitehead's philosophy of process (see Stengers 2011);

c. a deep engagement with philosophies and genealogies of 'the event' from Whitehead up to Foucault and Deleuze (see Shaviro 2012);

d. the philosophical problems and prospects offered by the movement of speculative realism in challenging our ways of thinking 'the real' (see Debaise 2017);

e. the various discussions and interpretations revolving around the Baradian ethico-onto-epistemology and its effects (see Barad 2007);

f. the acknowledgement of the political significance of the posthuman turn that Rosi Braidotti's philosophical work has brought to the fore (see Braidotti 2013); In light of the above, taking seriously the collapse of the subject/object divide and acknowledging non-human agencies in doing research is I think a major contribution of new materialism inspired methodologies. Manuel Delanda's exposition and reconfiguration of Deleuze and Guattari's notion of the assemblage as the 
methodological underpinning of new materialist research is in my view a major contribution (2006). As I understand it however, assemblage approaches in the field are still thin on the ground and they often appear as wooly and fuzzy; we need many more dissections and nuanced expositions of situated research case studies, but this phase will come later, since we are still in the phase of experimenting and trying to understand what it is exactly that we have been doing.

Having identified the most important contributions of new materialism conceptually and methodologically, it is also important to trace epistemological and philosophical trajectories leading up to the plane of new materialism as I see it today:

a. Spinoza's Ethics (1677)

b. Locke's (1690) and Hume's (1748) empiricism

c. Marx's dialectical materialism (1845)

d. Bergson's philosophy of time (1893)

e. James' radical empiricism (1807)

f. Whitehead's process philosophy (1929)

g. Langer's aesthetics and theories of art (1951)

h. Lefebvre's spatial analytics (1991)

i. Foucault's genealogies (1986)

j. Deleuze's radical immanence (2004)

k. Deleuze and Guattari's assemblages (1988)

I. Serre's philosophy and histories of science (2006)

m. Laruelle's non-philosophies (2013)

n. Haraway's situated knowledges (1988)

o. Latour's actor network theory (2005)

p. Material feminisms (Alaimo and Heckman 2008) 
Given their diversity and multiplicity then, if we are to summarise the epistemological and political contributions of new materialist perspectives and methodologies, taken as an assemblage rather than as a framework, I would argue that they intensify our awareness of our entanglement with the world, our immersion in on-going processes of transition and change, as well as the ontico-ethic (?) responsibility and effects of our thinking and action. New materialist perspectives radically change the way we see and understand nature and the social and force us to think differently whether as researchers, educators, citizens, political activists, or simply, human beings.

\section{Bibliography}

Alaimo Stacy and Heckman Susan (2008). (Eds) Material Feminisms. Bloomington: Indiana University Press.

Arendt, Hannah (1998) [1958]. The Human Condition. Chicago: The University of Chicago Press.

Bakhtin, Mihail (1981). The dialogic Imagination ed. by M. Holquist, Austin: University of Texas Press.

Barad, Karen (2007). Meeting the Universe Halfway: Quantum Physics and the Entanglement of Matter and Meaning. Durham: Duke University Press.

Bergson, Henri (2002) [1893]. Matter and Memory. Translated from the French by Nancy M. Paul and W. Scott Palmer. New York: Zone Books.

Braidotti, Rosi. (2013). The Posthuman. Cambridge: Polity Press.

Cavarero, Adriana (2000). Relating Narratives: storytelling and selfhood, translated by Paul, A. Kottman. London, Routledge.

Debaise, Didier (2017). Nature as Event: The Lure of the Possible, M. Halewood, trans., Durham: Duke University Press. 
DeLanda, Manuel (2006). A New Philosophy of Society: Assemblage Theory and Social Complexity. London: Continuum.

De Lauretis, Theresa (1988). Desire in Narrative. In Alice Doesn't : Feminism, Semiotics, Cinema. London: Macmillan.

Deleuze, Gilles (2004). Difference and Repetition. Translated by Paul Patton. London: Continuum.

Deleuze, Gilles \& Guattari, Felix (1988). [1980] A Thousand Plateaus: Capitalism and Schizophrenia, translated by Brian Massumi. London: The Athlone Press.

Elliot, Jane (2005). Using Narrative in Social Research: Qualitative and Quantitative Approaches, London, Sage.

Ferguson Kathy (2017). Feminist Theory Today. The Annual Review of Political Science, 20:14.1-14.18, doi: 10.1146/annurev-polisci-052715-111648.

Foucault, Michel (1986). Nietzsche, Genealogy, History. Trans. Donald.F. Bouchard and S. Simon. In: Paul Rabinow, Ed. The Foucault Reader, Harmondsworth: Peregrine, 76-100.

Fox, Nick \& Alldred, Pam (2015). New materialist social inquiry: designs, methods and the research-assemblage. International Journal of Social Research

Methodology, 18 (4), 399-414.

Grosz, Elizabeth (2004). The Nick of Time: Politics, Evolution and the Untimely. Durham and London: Duke University Press.

Halewood, Michael (2013). A. N. Whitehead and Social Theory. London: Anthem Press.

Hume, David (1748). Philosophical Essays Concerning Human Understanding. London: A. Millar.

James, Susan (2000). The Power of Spinoza: Feminist Conjunctions. Hypatia, 15 (2), 40-58. 
James, William (1912) [1807]. The Will to believe and other essays. New York: Keagan Press, 145-183. (First published, 1807)

Haraway, Donna (1988). Situated Knowledges: The Science Question. Feminism and the Privilege of Partial Perspective, Feminist Studies, 14 (3), 575-599.

Hemmings, Clare (2011). Why Stories Matter: the political grammar of feminist theory, Durham: Duke University Press.

Langer, Susanne, K. (1951). [1942] Philosophy in a New Key: A Study. In the Symbolism of Reason, Rite and Art. New York: Mentor Book.

Laruelle, François (2013) [1996]. Principles of Non-Philosophy, trans. Nicola Rubczak and Anthony Paul Smith. London: Bloomsbury.

Latour, Bruno (2005). Reassembling the Social: An Introduction to Actor-Network Theory. New York: Oxford University Press.

Lefebvre, Henri (1991) [1974]. The Production of Space, translated by Donald Nicholson- Smith, Oxford: Blackwell.

Livholts, Mona \& Tamboukou, Maria (2015). Discourse and Narrative Methods: Theoretical Departures, Analytical Strategies and Situated Writings. London: Sage. Lloyd, Genevieve (1996). Spinoza and the Ethics, London: Routledge. Locke, John (1690). An Essay Concerning Human Understanding. London: The Baffet.

Marx, Karl and Engels Friedrich. 1845. The German Ideology. Moscow: MarxEngels Institute (1932).

Moore, Niamh; Salter, Andrea; Stanley, Liz \& Maria Tamboukou (2016). The Archive Project: Archival Research. In the Social Sciences. London: Routledge.

Serres, Michel (2006). Récits d'humanisme. Paris: Le Pommier.

Shaviro, Steven (2012). Without Criteria: Kant, Whitehead, Deleuze and Aesthetics. Cambridge MA: The MIT Press. 
Spinoza, Baruch (1982) (1677) Ethics. (S. Feldman Ed., S. Shirley,Trans.). Indianapolis, IN: Hackett.

Stengers, Isabelle (2011), Thinking with Whitehead, trans. M. Chase. Cambridge, MA: Harvard University Press.

Tamboukou, Maria (2003). Women, Education and the Self: a Foucauldian perspective. Basingstoke, Palgrave, Macmillan.

Tamboukou, Maria (2010). In the Fold Between Power and Desire; Women Artists' Narratives. Newcastle-upon-Tyne: Cambridge Scholars Publishing.

Tamboukou, Maria (2014). Archival Research. Unravelling space/time/matter entanglements and fragments'. Qualitative Research 14(5), 617-633.

Tamboukou, Maria (2015a). Becomings: Narrative entanglements and microsociology. Forum Qualitative Social Research, 16 (1). Art. 19.

Tamboukou, Maria (2015b). Sewing, Fighting and Writing: Radical Practices in Work, Politics and Culture, London: Rowman \& Littlefield.

Tamboukou, Maria (2016). Feeling Narrative in the Archive: The Question of Serendipity, Qualitative Research 16(2), 151-166.

Tamboukou, Maria (2018). Numbers and Narratives: a feminist genealogy of automathographies, https://sites.google.com/view/numbersandnarratives/afeminist-genealogy-of-automathographies

Tamboukou, Maria (2019). Archives, Genealogies and Narratives in Women Workers' Education. Women's History Review (forthcoming).

Van der Tuin, Iris (2014). Diffraction as a methodology for Feminist Ontoepistemology: On encountering Chantal Chawaf and Posthuman interpellation. Parallax, 20 (3): $231-244$.

Van der Tuin, Iris (2015). Generational Feminism: New Materialist Introduction to a Generative Approach. Maryland: Lexington Books. 
Whitehead, Alfred, N., (1985) [1929]. Process and Reality [Corrected Edition], eds. Griffin D. R. and Sheburne D.W. New York: The Free Press. 